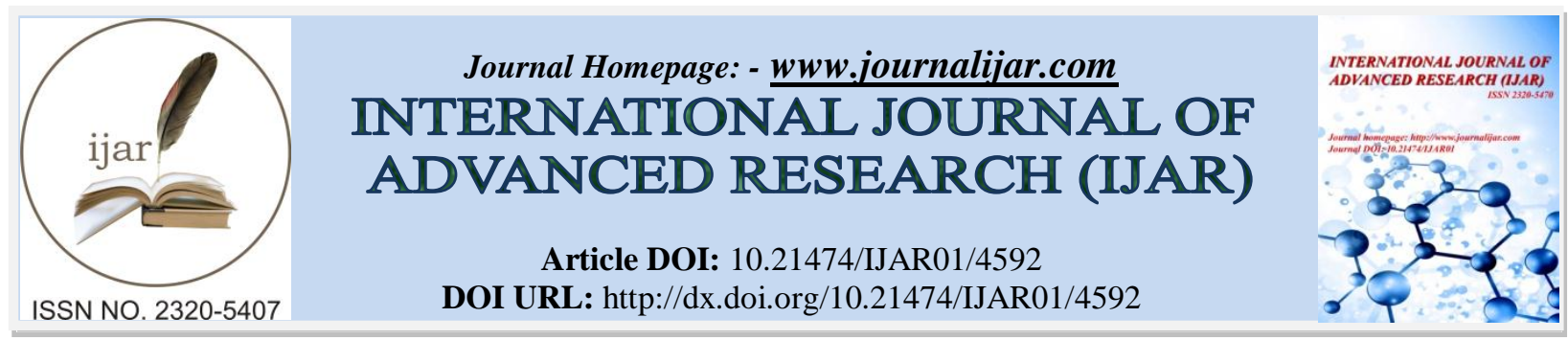

RESEARCH ARTICLE

\title{
EFFECT OF GUIDED BONE REGENERATION ON RIDGE SPLITTING WITH OR WITHOUT EXPANSION IN ADULTS: A SYSTEMATIC REVIEW.
}

\begin{abstract}
Ahmed Hanafy ${ }^{1}$ Samar El Kholy ${ }^{2}$ and Basma Mostafa ${ }^{3}$.
1. Assistant Lecturer, Department of Periodontology, Faculty of Dentistry, Beni-Suef University, Egypt.

2. Professor, Department of Periodontology, Faculty of Oral and Dental Medicine, Cairo University, Cairo, Egypt.

3. Assistant Professor, Department of Surgery and Oral Medicine, National Research Centre, Cairo, Egypt.
\end{abstract}

\section{Manuscript Info}

Manuscript History

Received: 24 April 2017

Final Accepted: 26 May 2017

Published: June 2017

Key words:-

Ridge splitting, Expansion, Guided bone regeneration.

\section{Abstract}

Background: Several modifications have been applied to the ridge splitting with or without expansion technique to allow for implant placement in the atrophic ridges. Some studies utilized guided bone regeneration and others not.

Aim: This systematic review will try to present the different studies discussing the effects of conjunction of bone grafting materials and/or membranes or not with the ridge splitting with or without expansion for patients having insufficient bucco-palatal ridge width.

Methods: A thorough PUBMED (Medline) and COCHRANE databases search in addition to hand-search of journals of relevance was performed on related terms in the period from 1992 to 2016 and resulted in 3247 titles of which 21 abstracts were selected and collected as full articles for further evaluation while the rest were excluded by title or abstract. According to the inclusion criteria 14 studies were included and discussed in this article.

Results: Of the 14 studies included in the present study only one study (cohort-retrospective) compared ridge splitting with/without expansion technique alone and with guided bone regeneration. Twelve studies applied guided bone regeneration while three studies did not.

Conclusion: The studies included in the present review showed high success and survival rates of implants placed in narrow ridges where ridge splitting and/or expansion technique were used with/without the application of guided bone regeneration. While the conjunction of guided bone regeneration with the ridge splitting and/or expansion technique showed more complications than using the technique alone. Studies included in the present study were of high or moderate risk of bias with only one randomized controlled clinical trial. So, the results of the present study should be reviewed cautiously.

Copy Right, IJAR, 2017,. All rights reserved.

\section{Introduction:-}

In the recent decades, dental rehabilitation of partially or totally edentulous ridges with implants has become common practice with reliable long-term results ${ }^{1,2}$. Successful implant treatment depends on the presence of sufficient quantities of bone and favorable inter-maxillary relationship ${ }^{3,4}$. 
Various techniques have been implemented to overcome any deficiencies or unfavorable conditions. When the residual alveolar ridge is narrower than the optimally planned implant diameter, onlay bone grafts, horizontal guided bone regeneration, and ridge splitting techniques can be used ${ }^{2,5}$.

Splitting and expansion of the alveolar ridge with insertion of dental implants between the bony plates has been successfully used for about 20 years ${ }^{6-8}$. The ridge splitting technique has several advantages compared with other techniques. Secondary surgical sites are not a prerequisite, and simultaneous implant placement can be achieved during ridge splitting ${ }^{9}$.

The classical approaches for the splitting technique were generalized with the use of osteotomes. Since then, several modifications have been reported for the classical technique, such as the use of ultrasonic surgery ${ }^{10}$ or the staged ridge splitting technique ${ }^{11}$. Chiapasco et al ${ }^{12}$ cited the technique of sagittal osteotomy of the anterior maxilla with preservation of the buccal cortex periosteum and vascularization with a half-thickness flap, stating that this technique resulted in better outcomes than other techniques. Many studies have been performed using barrier membranes ${ }^{8,13}$ and/or various bone grafting materials ${ }^{14}$ after ridge splitting.

This systematic review will try to present the effects of conjunction of bone grafting materials and/or membranes with the ridge splitting with/without expansion for patients with one or more missing teeth having insufficient bucco-palatal ridge width.

\section{Methods:-}

This review aimed to focus on the different studies reporting the techniques of ridge splitting and expansion with simultaneous implant placement both with and without the use of guided bone regeneration approaches. First a search was done on Medline (PubMed) using the following keywords: "ridge splitting and expansion" or "ridge splitting" or "ridge expansion" or "alveolar ridge expansion" or "alveolar ridge splitting" or "alveolar ridge augmentation" or "distraction osteogenesis" or "horizontal distraction osteogenesis" or "alveolar split osteotomy" or "sagittal split osteotomy" or "sagittal osteotomy" or "osseous expansion" and "oral implants" and "dental implants". This was followed by searching on Cochrane database using the same keywords as mentioned before. In addition, hand searching in the international journals in the scope of Implantology namely (The International Journal of Oral \& Maxillofacial Implants, Clinical Oral Implants Research, Journal of Oral and Maxillofacial Surgery, Dental implants, Journal of Oral and Maxillofacial Surgery, International Journal of Oral and Maxillofacial Surgery, Journal of Oral Implantology and Implant Dentistry) was done.

Studies were selected according to the following inclusion and exclusion criteria:

\section{Inclusion criteria:-}

- Randomized controlled clinical trials, cohort studies or case series were included.

- Studies included adult patients with one or more missing teeth in the upper or lower arches (anterior and posterior) with insufficient bucco-palatal (lingual) ridge width.

- Studies included ridge splitting with/without expansion technique and with/without using guided bone regeneration in conjunction with simultaneous implant placement.

- Studies included patients with sufficient vertical bone height.

\section{Exclusion criteria:-}

- Staged placement of implants.

- Use of distraction osteogenesis devices.

- Non clinical trials.

- Review articles.

\section{Study selection:-}

The first search yielded 3247 (after removal of duplicates studies) that have been screened according to the titles and abstracts (Figure 1). Twenty studies were chosen according to the before mentioned inclusion and exclu sion criteria for full copy reviewing. Bibliographies of selected articles were further searched for potentially relevant articles. Hand search revealed only one paper for full document reviewing. Seven studies were excluded after reviewing of full copies as shown in table (1). Fourteen studies fulfilling the inclusion and exclusion criteria were selected to perform this review. The selected articles were studied according to the augmentation of ridge splitting and 
expansion technique with guided bone regeneration or not, implant survival and success rates, change in alveolar bone dimensions over follow up periods, complications and types of bone substitutes and membranes utilized.

Figure 1:- Flow chart of search strategy

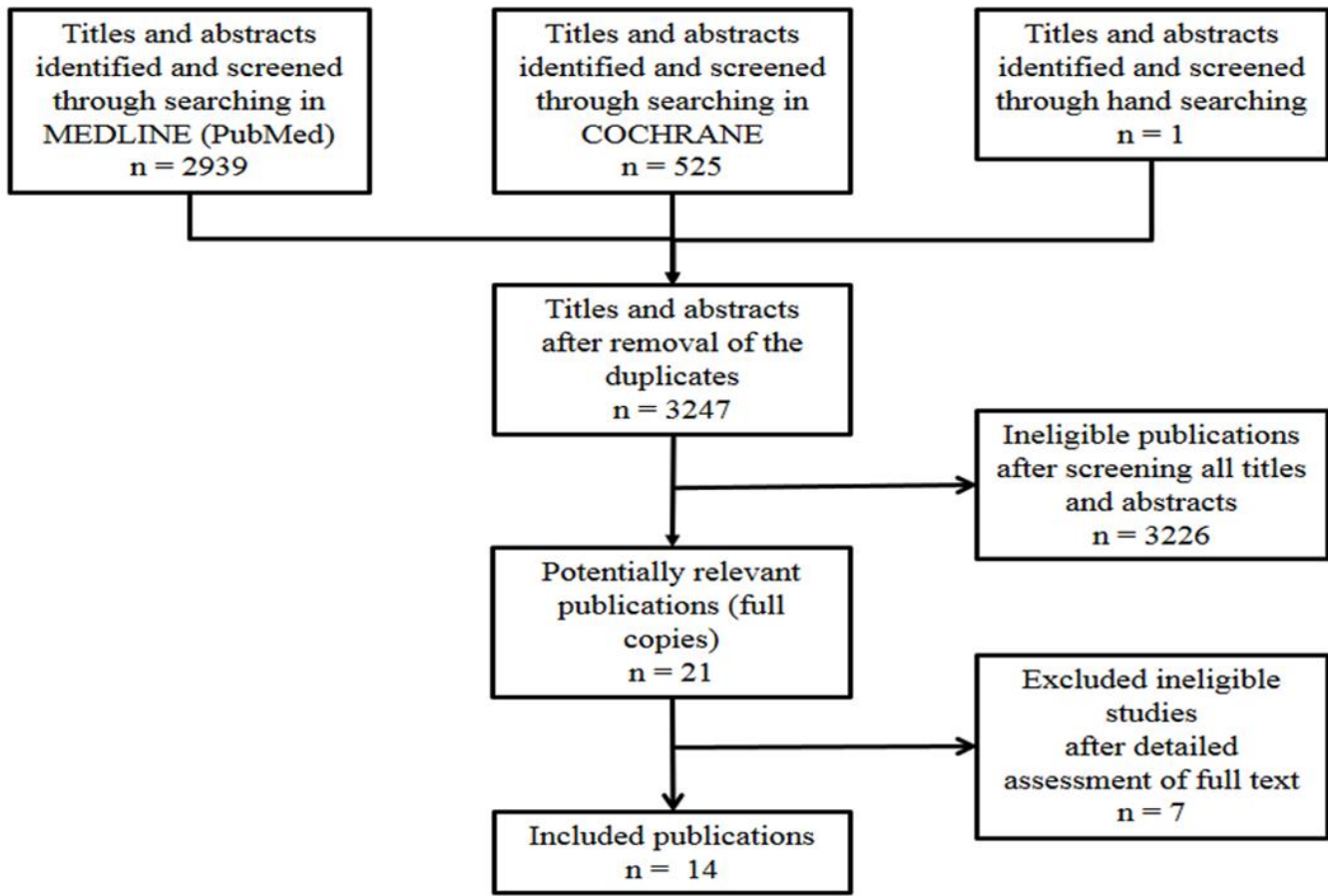

Table 1:- Studies excluded after detailed assessment of full text and the reason of exclusion.

\begin{tabular}{|l|l|}
\hline Study & Reason of exclusion \\
\hline Blus and Szmukler-Moncler [10] & Patients received GBR or not were included in the same group \\
\hline Jensen et al [32] & Patients received GBR or not were included in the same group \\
\hline Demetriades et al [33] & $\begin{array}{l}\text { Patients received one-stage and two-stage procedures were included in the } \\
\text { same group }\end{array}$ \\
\hline Scarano et al [27] & Two-stage procedure were used \\
\hline Montero et al [34] & Patients received GBR or not were included in the same group \\
\hline Anitua et al [35] & Patients received GBR or not were included in the same group \\
\hline Shibuya et al [36] & The study only measures cases with complications \\
\hline
\end{tabular}

\section{Critical appraisal:-}

Risk of bias was assessed according to study design, randomized selection, specification of the inclusion/exclusion criteria, reporting of lost follow-up and complications, objective evaluation and statistical analysis of the results.

\section{Results:-}

The selected 14 studies were divided according to the study design into 1 randomized controlled trial (RCT), 5 cohort studies and 8 case series studies. The articles collected were published in the period from 1992 to 2016 . Data was collected from the selected articles in customized forms and tabulated as shown in table (2). Only one study (cohort-retrospective) ${ }^{1}$ compared ridge splitting and expansion alone and with guided bone regeneration. And so, three studies did not apply guided bone regeneration while twelve studies applied it. 
Table 2:- List of selected articles.

\begin{tabular}{|c|c|c|c|c|c|c|c|c|}
\hline & Study & $\begin{array}{l}\text { Study } \\
\text { Design }\end{array}$ & $\begin{array}{l}\text { No of } \\
\text { Implants }\end{array}$ & Flap Design & $\begin{array}{ll}\text { Type of } \\
\text { Bone } \\
\text { Graft }\end{array}$ & $\begin{array}{l}\text { Type of } \\
\text { Membranes }\end{array}$ & $\begin{array}{l}\text { Cumulat } \\
\text { ive } \\
\text { Survival } \\
\text { Rate }\end{array}$ & $\begin{array}{l}\text { Cumulati } \\
\text { ve Success } \\
\text { Rate }\end{array}$ \\
\hline 1 & $\begin{array}{lr}\text { Simion et } \\
\text { al. } 1992 \\
{[8]}\end{array}$ & $\begin{array}{l}\text { Case } \\
\text { series }\end{array}$ & 10 & $\begin{array}{l}\text { Full } \\
\text { thickness }\end{array}$ & - & $\begin{array}{l}\text { Non- } \\
\text { Resorbable }\end{array}$ & $\begin{array}{l}\text { Not } \\
\text { mentione } \\
\mathrm{d}\end{array}$ & $100 \%$ \\
\hline 2 & $\begin{array}{lr}\text { Engelke et } \\
\text { al. } 1997 \\
{[22]}\end{array}$ & $\begin{array}{l}\text { Case } \\
\text { series }\end{array}$ & 124 & $\begin{array}{l}\text { Full } \\
\text { thickness }\end{array}$ & Alloplast & $\begin{array}{l}\text { Non- } \\
\text { Resorbable }\end{array}$ & $\begin{array}{l}\text { Not } \\
\text { mentione } \\
\mathrm{d}\end{array}$ & $86.2 \%$ \\
\hline 3 & $\begin{array}{l}\text { Sethi and } \\
\text { Kaus. } 2000 \\
{[23]}\end{array}$ & $\begin{array}{l}\text { Case } \\
\text { series }\end{array}$ & 449 & $\begin{array}{l}\text { Partial } \\
\text { thickness }\end{array}$ & $\begin{array}{l}\text { Autogenou } \\
\text { s } \\
\text { Alloplast }\end{array}$ & Not mentioned & $\begin{array}{l}\text { Not } \\
\text { mentione } \\
\mathrm{d}\end{array}$ & $97 \%$ \\
\hline 4 & $\begin{array}{l}\text { Chiapasco } \\
\text { et al. } 2006 \\
\text { [16] }\end{array}$ & $\begin{array}{l}\text { Case } \\
\text { series }\end{array}$ & 110 & $\begin{array}{l}\text { Full } \\
\text { thickness }\end{array}$ & 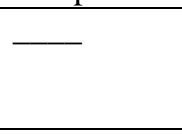 & 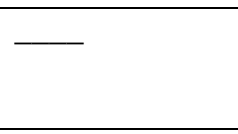 & $97.3 \%$ & $95.4 \%$ \\
\hline 5 & $\begin{array}{lr}\text { Danza et } \\
\text { al. } 2009 \\
{[15]}\end{array}$ & Cohort & 21 & $\begin{array}{l}\text { Full } \\
\text { thickness }\end{array}$ & - & 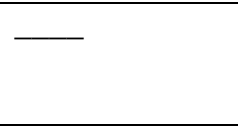 & $\begin{array}{l}\text { Not } \\
\text { mentione } \\
\mathrm{d}\end{array}$ & $95.3 \%$ \\
\hline 6 & $\begin{array}{l}\text { Sohn et al. } \\
2010 \text { [21] }\end{array}$ & Cohort & 63 & $\begin{array}{l}\text { Full } \\
\text { thickness }\end{array}$ & $\begin{array}{l}\text { Allograft + } \\
\text { Xenograft } \\
\end{array}$ & Resorbable & $100 \%$ & $\begin{array}{l}\text { Not } \\
\text { mentioned }\end{array}$ \\
\hline 7 & $\begin{array}{lr}\text { Langer et } \\
\text { al. } 2012 \\
{[24]}\end{array}$ & $\begin{array}{l}\text { Case } \\
\text { series }\end{array}$ & 37 & $\begin{array}{l}\text { Full } \\
\text { thickness }\end{array}$ & Allograft & Not mentioned & $100 \%$ & $\begin{array}{l}\text { Not } \\
\text { mentioned }\end{array}$ \\
\hline 8 & $\begin{array}{l}\text { Bassetti et } \\
\text { al. } 2013 \\
{[18]}\end{array}$ & Cohort & 36 & $\begin{array}{l}\text { Partial } \\
\text { thickness }\end{array}$ & Xenograft & Resorbable & $100 \%$ & $\begin{array}{l}\text { Not } \\
\text { mentioned }\end{array}$ \\
\hline 9 & $\begin{array}{l}\text { Kolerman } \\
\text { et al. } 2013 \\
{[20]} \\
\end{array}$ & Cohort & 116 & $\begin{array}{l}\text { Full } \\
\text { thickness }\end{array}$ & Allograft & Resorbable & $100 \%$ & $\begin{array}{l}\text { Not } \\
\text { mentioned }\end{array}$ \\
\hline 10 & $\begin{array}{l}\text { Rehpeyma } \\
\text { et al. } 2013 \\
{[25]}\end{array}$ & $\begin{array}{l}\text { Case } \\
\text { series }\end{array}$ & 82 & $\begin{array}{l}\text { Full } \\
\text { thickness }\end{array}$ & Xenograft & Not mentioned & $100 \%$ & $\begin{array}{l}\text { Not } \\
\text { mentioned }\end{array}$ \\
\hline 11 & $\begin{array}{l}\text { Tang et al. } \\
2013 \text { [1] }\end{array}$ & Cohort & $\begin{array}{l}113 \\
\left(\mathrm{RST}^{*}+\mathrm{GB}\right. \\
\left.\mathrm{R}^{* *}\right) \\
113 \text { (RST } \\
\text { only) }\end{array}$ & $\begin{array}{l}\text { Full } \\
\text { thickness } \\
\text { (RST+GBR } \\
\text { ) } \\
\text { Partial } \\
\text { thickness } \\
\text { (RST only) }\end{array}$ & $\begin{array}{l}\text { Xenograft } \\
\text { (RST } \\
\text { GBR) }\end{array}+$ & Resorbable & $\begin{array}{l}\text { (RST+G } \\
\text { BR) } \\
100 \% \\
93.2 \% \\
\text { (RST } \\
\text { only) }\end{array}$ & $\begin{array}{l}\text { (RST+GB } \\
\text { R) } 95.6 \% \\
100 \% \\
\text { (RST } \\
\text { only) }\end{array}$ \\
\hline 12 & $\begin{array}{lr}\text { Crespi et } \\
\text { al. } 2014 \\
{[19]}\end{array}$ & Cohort & 118 & $\begin{array}{l}\text { Partial } \\
\text { thickness }\end{array}$ & 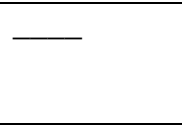 & Resorbable & $98.31 \%$ & $\begin{array}{l}\text { Not } \\
\text { mentioned }\end{array}$ \\
\hline 13 & $\begin{array}{l}\text { Garcez- } \\
\text { Filho et al. } \\
2014 \text { [26] }\end{array}$ & $\begin{array}{l}\text { Case } \\
\text { series }\end{array}$ & 40 & $\begin{array}{l}\text { Full } \\
\text { thickness }\end{array}$ & Xenograft & 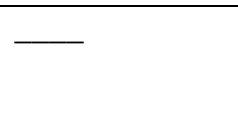 & $97 \%$ & $95 \%$ \\
\hline 14 & $\begin{array}{l}\text { Mounir et } \\
\text { al. } 2014 \\
{[17]}\end{array}$ & RCT & 43 & $\begin{array}{l}\text { Full/Partial } \\
\text { thickness }\end{array}$ & Alloplast & 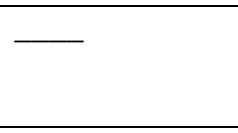 & $100 \%$ & $\begin{array}{l}\text { Not } \\
\text { mentioned }\end{array}$ \\
\hline
\end{tabular}

*Ridge splitting technique, ${ }^{* * \text { Guided bone regeneration }}$

Risk of bias in all selected articles was substantially high (table 3). This was due to the study designs which were mostly either cohort or case series, even the single randomized controlled trial included in the present review was of moderate risk of bias. It was not possible to perform a meta-analysis of the data because of the heterogeneity of the 
identified studies regarding surgical technique (instruments and devices used in ridge splitting, flap design, flap reflection technique and bone cut extension), grafting materials and membranes as well as follow-up periods. This systematic review will therefore only present the studies narratively

In all the selected papers the outcomes were objective regarding assessment of the implants success rate and implant supported prosthesis. Change in alveolar bone dimensions postoperatively was mentioned in some studies.

Table 3:- Risk of bias assessment for the selected studies:

\begin{tabular}{|c|c|c|c|c|c|c|c|c|c|}
\hline & Study & $\begin{array}{l}\text { Type } \\
\text { of } \\
\text { study }\end{array}$ & $\begin{array}{l}\text { Inclusion/ } \\
\text { exclusion } \\
\text { criteria }\end{array}$ & $\begin{array}{l}\text { Selection } \\
\text { randomization }\end{array}$ & $\begin{array}{l}\text { Reported } \\
\text { loss to } \\
\text { follow } \\
\text { up }\end{array}$ & $\begin{array}{l}\text { Reported } \\
\text { complications }\end{array}$ & $\begin{array}{l}\text { Objective } \\
\text { evaluation }\end{array}$ & $\begin{array}{l}\text { Statistical } \\
\text { analysis }\end{array}$ & $\begin{array}{l}\text { Risk of } \\
\text { bias }\end{array}$ \\
\hline 1 & $\begin{array}{l}\text { Simion et } \\
\text { al. } 1992 \\
{[8]}\end{array}$ & $\begin{array}{l}\text { Case } \\
\text { series }\end{array}$ & Yes & No & No & No & Yes & No & High \\
\hline 2 & $\begin{array}{l}\text { Engelke et } \\
\text { al. } 1997 \\
{[22]}\end{array}$ & $\begin{array}{l}\text { Case } \\
\text { series }\end{array}$ & No & No & Yes & Yes & Yes & No & High \\
\hline 3 & $\begin{array}{l}\text { Sethi and } \\
\text { Kaus. } \\
2000 \text { [23] }\end{array}$ & $\begin{array}{l}\text { Case } \\
\text { series }\end{array}$ & Yes & No & Yes & Yes & Yes & Yes & Moderate \\
\hline 4 & $\begin{array}{l}\text { Chiapasco } \\
\text { et al. } 2006 \\
\text { [16] }\end{array}$ & $\begin{array}{l}\text { Case } \\
\text { series }\end{array}$ & Yes & No & Yes & Yes & Yes & Yes & Moderate \\
\hline 5 & $\begin{array}{lr}\text { Danza et } \\
\text { al. } 2009 \\
{[15]}\end{array}$ & Cohort & Yes & No & No & No & Yes & Yes & High \\
\hline 6 & $\begin{array}{l}\text { Sohn et al. } \\
2010 \text { [21] }\end{array}$ & Cohort & No & No & No & Yes & No & No & High \\
\hline 7 & $\begin{array}{l}\text { Langer et } \\
\text { al. } 2012 \\
{[24]}\end{array}$ & $\begin{array}{l}\text { Case } \\
\text { series }\end{array}$ & No & No & No & No & Yes & Yes & High \\
\hline 8 & $\begin{array}{l}\text { Bassetti et } \\
\text { al. } 2013 \\
{[18]}\end{array}$ & Cohort & Yes & No & No & Yes & Yes & Yes & Moderate \\
\hline 9 & $\begin{array}{l}\text { Kolerman } \\
\text { et al. } 2013 \\
\text { [20] }\end{array}$ & Cohort & Yes & No & No & Yes & Yes & yes & Moderate \\
\hline 10 & $\begin{array}{l}\text { Rehpeyma } \\
\text { et al. } 2013 \\
\text { [25] }\end{array}$ & $\begin{array}{l}\text { Case } \\
\text { series }\end{array}$ & Yes & No & No & No & Yes & Yes & High \\
\hline 11 & $\begin{array}{l}\text { Tang et al. } \\
2013 \text { [1] }\end{array}$ & Cohort & Yes & No & Yes & Yes & Yes & Yes & Moderate \\
\hline 12 & $\begin{array}{l}\text { Crespi et } \\
\text { al. } 2014 \\
{[19]}\end{array}$ & Cohort & Yes & No & No & Yes & Yes & Yes & Moderate \\
\hline 13 & $\begin{array}{l}\text { Garcez- } \\
\text { Filho et al. } \\
2014 \text { [26] }\end{array}$ & $\begin{array}{l}\text { Case } \\
\text { series }\end{array}$ & Yes & No & No & No & Yes & Yes & Moderate \\
\hline 14 & $\begin{array}{l}\text { Mounir et } \\
\text { al. } 2014 \\
{[17]}\end{array}$ & RCT & Yes & Yes & No & No & Yes & Yes & Moderate \\
\hline
\end{tabular}

Group (1) Ridge splitting and expansion without guided bone regeneration:-

Three studies applied ridge splitting and expansion technique without guided bone regeneration ( 2 cohort studies ${ }^{1,15}$ and 1 case series study ${ }^{16}$. 244 implants were placed in split crest sites. Two studies ${ }^{15,16} \mathrm{did}$ not assess patients for 
smoking habits while the third one reported smoking habits for the patients ${ }^{1}$. The three studies applied the technique in the upper and lower arches (anterior and posterior). Initial alveolar ridge width was specified by Chiapasco et al 16 and Tang el $\mathrm{al}^{1}$ as 3-7 $\mathrm{mm}$ and $2 \mathrm{~mm}$ respectively, while it was subjectively mentioned by Danza et al ${ }^{15}$.

Full thickness flap design was applied by Chiapasco et al ${ }^{16}$ and Danza et al ${ }^{15}$, while partial thickness flap was performed by Tang el al ${ }^{1}$. Regarding the methods which were used for ridge splitting and expansion, Chiapasco et al used oscillating saw for splitting with extension crest devices for expansion ${ }^{16}$. Tang el a ${ }^{1}$ mentioned the use of a specialized fine bone chisel for splitting with specific extension crest device for expansion, while Danza et al ${ }^{15}$ reported the use of piezoelectric surgical device for splitting. The three studies utilized periapical radiographs for assessment of implants in the follow-up periods; moreover Tang el al ${ }^{1}$ performed panoramic radiographs. Time of implants loading was specified by Chiapasco et al ${ }^{16}$ (3-4 months), Danza et al ${ }^{15}$ (6-8 months) and Tang el al ${ }^{1}$ (4-6 months).

Regarding the outcomes, the width gain of the edentulous ridge at the end of the expansion procedure was mentioned by Chiapasco et al ${ }^{16}$ which ranged from $2-5 \mathrm{~mm}$, while this was not mentioned by Danza et al ${ }^{15}$ or Tang el al ${ }^{1}$. Chiapasco et al reported the mean bone width variation of the expanded crest between implant placement and abutment connection, and between abutment connection and 1-2 years after the start of prosthetic loading which were $-0.4,-0.5,-0.8$, and $-0.8 \mathrm{~mm}$, respectively (measurements were made approximately $1 \mathrm{~mm}$ below the crestal margin and were taken to the nearest $0.5 \mathrm{~mm})^{16}$. Tang el al noted that the vertical bone loss after expansion was $1.61 \pm 0.91 \mathrm{~mm}$ during 5.8 months of unloaded healing, while the marginal bone loss was $0.69 \pm 0.49 \mathrm{~mm}$ in the first year, followed by $0.07,0.06,0.06,0.06$, and $0.09 \mathrm{~mm}$ annually ${ }^{1}$.

Regarding complications, Chiapasco et al ${ }^{16}$ reported prolonged pain in the expanded area in one patient which resolved spontaneously 1 month postoperatively. Tang el al ${ }^{1}$ reported some complications which were mentioned generally for the two study groups (ridge expansion alone and in combination with guided bone regeneration), so we could not mention these complications in the results. Danza et al did not report any complications during the surgical procedure or postsurgical ${ }^{15}$.

Regarding cumulative survival and success rates, Chiapasco et al stated that the overall success rate of the surgical procedure, cumulative survival rate and success rate of implants placed in the expanded sites at the end of the follow-up period were $97.8 \%, 97.3 \%$ and $95.4 \%$ respectively ${ }^{16}$. Danza et al noticed failure in 1 implant (after 1 month of placement) among 21 implants placed with piezo split crest surgical technique with cumulative success rate of $95.3 \%{ }^{15}$. Tang el al noted that the 8 years' cumulative implant success and survival rates of the implants placed in the expanded sites were $93.2 \%$ and $100 \%$ respectively ${ }^{1}$.

\section{Group (2) Ridge splitting and expansion in conjunction with guided bone regeneration:-}

Twelve studies applied ridge splitting and expansion with guided bone regeneration in the same surgical procedure ( 1 randomized controlled trial ${ }^{17}, 5$ cohort studies ${ }^{1,18-21}$ and 6 case series studies ${ }^{8,22-26}$. 1118 implants were placed in the split crest sites. Assessment for smoking habits was unclear in 6 studies ${ }^{8,21-25}$. Patients were all smokers in 2 studies ${ }^{20,26}$, while in 4 studies ${ }^{1,17-19}$ patients were non-smokers.

Eleven studies applied the technique in the upper arch anteriorly ${ }^{1,8,17-20,22-25}$, posterior ${ }^{1,8,18-20,22-26}$, while 8 papers applied the technique in the lower arch namely anterior $1,8,18,19,22,24,25$ and posterior 1, 8, 18, 19, 21, 22, 24, 25. Initial alveolar ridge width was different between the studies with a range between $1.5-5 \mathrm{~mm}$, while in one study ${ }^{22}$ it was not mentioned.

Full thickness flap was applied in 9 studies 1,8,17, 20-22,24-26, while partial thickness flap was applied in 5 studies $1,17-19$, 23. Regarding the methods used for ridge splitting, chisels and osteotomes have been used in 6 studies $1,8,17,19,20,23$, burs and discs have been used in 4 studies ${ }^{22,24-26}$, electrical mallet has been used in 1 study ${ }^{19}$ while piezo-electric device has been used in 3 studies $18,21,24$. Regarding the methods used for ridge expansion, chisels and osteotomes have been used in 8 studies ${ }^{17,19-23,25,26}$, wedges have been used in 1 study ${ }^{18}$ while extension crest device has been used in another study ${ }^{1}$.

Regarding bone grafts and membranes used, 6 studies applied bone grafts and membranes in conjunction with ridge splitting technique ${ }^{1,18,20-23}, 4$ studies used bone grafts only ${ }^{17,24-26}$ while 2 studies utilized membranes only ${ }^{8,19}$. Regarding types of bone grafts applied, 1 study used autogenous bone graft in conjunction with xenograft ${ }^{21}, 1$ study 
used autogenous bone graft in conjunction with alloplast ${ }^{23}, 2$ studies applied allografts ${ }^{20,24}$, 4 studies utilized xenograft $^{1,18,25,26}$, while 2 studies applied alloplasts ${ }^{17,22}$. Regarding types of membranes applied, 6 studies utilized resorbable membranes ${ }^{1,18-22}$ while 2 studies used non-resorbable membranes ${ }^{8,22}$.

Regarding radiographic examination, periapical radiographs were performed in 9 studies 1, 20-27, panoramic radiographs were documented in 5 studies ${ }^{1,18,20-22}$, cone beam volumetric tomography was used in 2 studies ${ }^{17,21}$, computed tomography were done in 2 studies ${ }^{8,20}$.

Time of implants loading was specified by Simion et al ${ }^{8}$ (6 months for all cases, 10 months for 1 case with membrane dehiscence), Engelke et al ${ }^{22}$ (4-6 months), Sethi and Kaus ${ }^{23}$ (6 months), Sohn et al ${ }^{21}$ (17 months), Langer et al ${ }^{24}$ (4-17 months), Bassetti et al ${ }^{18}$ (4-8 months), Kolerman et al ${ }^{20}$ (6 months), Rehpeyma et al ${ }^{25}$ (3 months), Tang et al ${ }^{1}$ (4-6 months), Crespi et al ${ }^{19}$ (6 months), Garcez-Filho et al ${ }^{26}$ (6-8 months) while Mounir et al ${ }^{17}$ did not specify the time of implant loading.

Regarding the outcomes, Simion et al ${ }^{8}$ noted that average gain of ridge width was $2.6 \mathrm{~mm}$ (range:1-4 mm) while the average loss of ridge height at stage-two surgery (6 months for 9 patients and 10 months for 1 patient) was $0.5 \mathrm{~mm}$. Engelke et al ${ }^{22}$ noted that the mean postoperative marginal bone loss (mesial and distal surfaces of each implant) after an interval of less than 1 year was $1.1 \mathrm{~mm}, 2$ to 3 years it was $2.0 \mathrm{~mm}$, and 3 to 5 years it reached $1.9 \mathrm{~mm}$, Bassetti et al ${ }^{18}$ measured the average increase in bone width at the time of ridge splitting procedure with implant placement $(4.7 \pm 0.8 \mathrm{~mm})$, changes in peri-implant marginal bone levels between time of surgery and time of loading (4-8 months after surgery) it was $-1.18 \pm 1.06 \mathrm{~mm}$ mesially and $-1.2 \pm 0.99 \mathrm{~mm}$ distally, time of loading and after 1 year it is $-0.65 \pm 0.98 \mathrm{~mm}$ mesially and $-0.53 \pm 0.91 \mathrm{~mm}$ distally, 1 year and 2 years of loading was $-0.05 \pm$ $0.03 \mathrm{~mm}$ mesially and $-0.05 \pm 0.02 \mathrm{~mm}$ distally and between time of surgery and 2 years of loading was $-1.66 \pm 1.08$ $\mathrm{mm}$ mesially and $-1.69 \pm 0.9 \mathrm{~mm}$ distally, Kolerman et al ${ }^{20}$ reported that the difference in ridge width (between preoperative and postoperative measurements) averaged $3.5 \pm 0.93 \mathrm{~mm}$. The initial buccal bonny plate after implant installation varied between 0.5 and $1 \mathrm{~mm}$ (mean: $0.86 \pm 0.21 \mathrm{~mm}$ ). At 6 months postoperatively, the width of the buccal plates ranged between 2 and $4 \mathrm{~mm}$ (average: $2.80 \pm 0.64 \mathrm{~mm}$ ). The average difference in width was $1.90 \pm$ $0.59 \mathrm{~mm}$. The mean vertical mesial bone loss was $1.81 \mathrm{~mm} \pm 1.07$, and the mean vertical distal bone loss was 1.74 $\mathrm{mm} \pm 1.12$. In eight patients, at least one implant presented bone loss of $\geq 3 \mathrm{~mm}$, Rehpeyma et al ${ }^{25}$ reported that the mean gain in crest ridge after ridge split was $2 \pm 0.3 \mathrm{~mm}$. Tang et al ${ }^{1}$ reported that in the group where patients received ridge splitting in conjunction with guided bone regeneration the vertical bone loss after expansion was 1.60 $\pm 0.81 \mathrm{~mm}$ (range: $-0.05-3.33 \mathrm{~mm}$; median: $1.63 \mathrm{~mm}$ ) after 7 months of unloaded healing, while the marginal bone loss was $0.43 \pm 0.51 \mathrm{~mm}$ during the first year, followed by 0.06, 0.08, 0.06, 0.08, and 0.09 mm annually. Crespi et al ${ }^{19}$ reported that the final ridge width gained varied from $5-8 \mathrm{~mm}$ (average $7.2 \pm 1.7 \mathrm{~mm}$ ). Garcez-Filho et al ${ }^{26}$ documented that the marginal bone loss around implants was $0.47 \pm 0.91 \mathrm{~mm}$ at 6 months after loading and $1.93 \pm$ $0.93 \mathrm{~mm}$ at 10 years follow up after loading. While Mounir et al ${ }^{17}$ reported that the mean marginal bone loss (in a follow up of 6 months postoperatively) of the labial plate in the control group (ridge-splitting technique using a full thickness mucoperiosteal flap) was found to be $2.29 \mathrm{~mm}(15.36 \%)$, while in the study group (ridge splitting technique using a partial thickness mucosal flap) it was $0.71 \mathrm{~mm}(5.89 \%)$. The mean palatal marginal bone loss in the control group was $2.48 \mathrm{~mm}(16.84 \%)$ and that in the study group it was $1.14 \mathrm{~mm}(8.99 \%)$. The results also showed the mean mesio-distal marginal bone loss in the control group to be $1.83 \mathrm{~mm}(12.21 \%)$, while that in the study group was $1.15 \mathrm{~mm}(8.77 \%)$.

Regarding the complications, Simion et al $^{8}$ reported a dehiscence of the membrane (non-resorbable) in one patient with two implant sites which occurred after 2 months of healing; the membrane was removed because of severe inflammation at the margins of the exposed area. Sethi and Kaus ${ }^{23}$ reported sudden increase in the incidence of infection in 2 cases, and this practice was terminated. Kolerman et al ${ }^{20}$ reported spontaneous exposure which occurred in 18 implants $(15.5 \%)$. Spontaneous exposures were treated by replacement of the cover screw with healing abutments. In cases where there was insufficient buccal band of keratinized gingiva, masticatory mucosa pedicle flap was displaced from the palate adjacent to the implant. Membrane exposure occurred at five sites in five different patients (14\%). No exposure demanded premature removal of the membrane because the exposed portions of the membrane were absorbed shortly after. As mentioned above that Tang et al ${ }^{1}$ reported some complications but they were mentioned generally for the two study groups (ridge expansion alone and combined with guided bone regeneration), so we could not mention these complications in the results separately. 
Regarding cumulative survival and success rates, Simion et al ${ }^{8}$ reported $100 \%$ success of implants at time of implants loading (6-10 months from placement time), Engelke et al ${ }^{22}$ reported that the 5-year cumulative success rate was $86.2 \%$, Sethi and Kaus ${ }^{23}$ mentioned that the 5-year follow up success rate was $97 \%$, Sohn et al ${ }^{21}$ noted no failures after 4-5 months of placement. Langer et $\mathrm{al}^{24}$ showed that the cumulative survival rate of implants in 4-year follow up is $100 \%$, Bassetti et al ${ }^{18}$ reported that implants survival rate after 2 years of follow up was $100 \%$, Kolerman et al ${ }^{20}$ documented that the overall implant survival rate after 5 years of follow up was $100 \%$. Rehpeyma et $\mathrm{al}^{25}$ after at least 6 months of follow up showed that all implants survived and were functional. Tang et al ${ }^{1}$ noted that the 8 years' cumulative implant success and survival rates of the implants placed in the expanded sites were $95.6 \%$ and $100 \%$ respectively. Crespi et al ${ }^{19}$ reported that the survival rate at 2 -year follow up was $98.31 \%$, GarcezFilho et al ${ }^{26}$ presented that the 10-year time interval the implant survival rate was $97 \%$ and the success rate was 95\% while Mounir et al ${ }^{17}$ showed no failure implants in both study and control groups (ridge splitting with full thickness and partial thickness flaps) in a follow up period of 6 months after implant placement.

\section{Discussion:-}

Initial reports on the ridge-splitting technique described it as a successful surgical technique that could be used simultaneously with implant placement. In their original reports, Simion et al ${ }^{8}$ and Scipioni et al ${ }^{28}$ reported 1 to 4 $\mathrm{mm}$ of alveolar width gain after the split-crest procedure and successful immediate implant placement and osseointegration. This surgical technique involved splitting the alveolar ridge longitudinally in two parts, provoking a longitudinal greenstick fracture at the top of the bone to create a space-making defect. This technique prevents the need for onlay grafts taken from the maxillary tuberosity, symphysis of the chin, the external oblique ridge, or the hip presenting postoperative morbidity associated with bone harvesting ${ }^{29}$.

The current review was conducted to focus on the effects of conjunction of guided bone regeneration with the ridge splitting with or without expansion. The results of this review showed that few studies fulfilled the inclusion and exclusion criteria with only three studies applied ridge splitting with/without expansion without the conjunction with guided tissue regeneration, while twelve studies applied guided bone regeneration, regarding that one cohort retrospective study compared both modalities and was included in both groups of the present review.

In the present review we noted heterogeneity of the identified studies regarding surgical technique (instruments and devices used in ridge splitting, flap design, flap reflection technique and bone cut extension), grafting materials and membranes as well as follow-up period. This resulted in the lack of possibility to perform a meta-analysis of the data and so the studies in this systematic review were only presented narratively. Moderate to high risk of bias was revealed for the selected studies. This is an important factor to be put into consideration when reviewing the results of this systematic review.

One study ${ }^{16}$ was included where a device was used to expand the buccal and palatal/lingual plates after splitting; some implants were placed 7 days after the splitting procedure to allow for the activation of the expansion device within some days in the mandibular defects with very dense bone. The device used in this study could not be considered as a distraction osteogenesis device as the aim was not to generate new soft tissue and bone. Regarding the implants placed in few days after splitting, we could not refer this to staged implant placement procedure, as the aim of this step was to wait until getting enough expansion from the splitting.

In group (1), the cumulative survival rate was measured in only 1 study ${ }^{1}$ and it was $100 \%$ with follow up period of 8 years. While in group (2), 10 studies $1,8,17,18,19,20,21,24,25,26$ reported the cumulative survival rate which ranged between $97-100 \%$. Bassetti et al ${ }^{30}$ in their systematic review noted cumulative survival rate in 18 studies which ranged between $91.7-100 \%$, while in another systematic review Elnayef et al ${ }^{31}$ reported implant survival rate in between $94 \%$ to $100 \%$. In comparison with the two groups presented in the present study, Bassetti et al ${ }^{30}$ showed wider range of cumulative survival rate with less lower limit, while Elnayef et al $^{31}$ results were more comparable with the results of the two groups in the current review.

In group (1), the cumulative success rate of implants was measured in the three studies ${ }^{1,15,16}$ and it ranged between 93.2-95.4\% with the maximum follow up period of 8 years. In group (2), 4 studies measured the cumulative success rate $^{1,22,23,26}$, and it was between $86.2-97 \%$ with the maximum follow up period of 8 years also. And so the results of cumulative success rates of the second group are slightly higher than the first group. Bassetti et $\mathrm{al}^{30}$ in its review, cumulative survival rates were between $88.2-100 \%$ in 9 studies. So the results of group (2) are comparable with Bassetti et $\mathrm{al}^{30}$, while group (1) showed better results than group (2) and better results in comparison with Bassetti 
et $\mathrm{al}^{30}$ regarding the lower limit of success rates while the upper limit showed better results for Bassetti et al ${ }^{30}$. These differences in results could be attributed to the differences in definitions of success criteria, designs of implants, inclusion and exclusion criteria, or operational details in the conducted studies.

In group (1), one study ${ }^{1}$ reported that in the group where patients received ridge splitting and expansion alone the bone loss (vertically) after expansion was $1.61 \pm 0.91 \mathrm{~mm}$ after 7 months of unloaded healing, and the average of marginal bone loss after loading was $0.69 \pm 0.49 \mathrm{~mm}$ during the first year followed by $0.07,0.06,0.06,0.06$, and 0.09 $\mathrm{mm}$ annually. Chiapasco et al ${ }^{16}$ reported the mean bone width variation of the expanded crest between implant placement and abutment connection, from 1-2 years after the start of prosthetic loading which were $-0.4,-0.5,-0.8$, and $-0.8 \mathrm{~mm}$, respectively. While in group (2), bone loss after ridge splitting with/without expansion technique were measured in 6 studies $1,17,18,20,22,26$. Engelke et al ${ }^{22}$ reported the mean of postoperative marginal bone loss (mesial and distal) in the follow up times of less than 1 year, 2 to 3 years and 3 to 5 years were 1.1, 2.0, and $1.9 \mathrm{~mm}$ respectively. Bassetti et al ${ }^{18}$ reported the changes in peri-implant marginal bone levels between time of surgery and time of loading (4-8 months after surgery), time of loading and after 1 year, 1 year and 2 years of loading and between time of surgery and 2 years of loading and they were $-1.18 \pm 1.06 \mathrm{~mm},-0.65 \pm 0.98 \mathrm{~mm},-0.05 \pm 0.03 \mathrm{~mm}$ and $-1.66 \pm 1.08 \mathrm{~mm}$ respectively for mesial measurements, and $-1.2 \pm 0.99 \mathrm{~mm},-0.53 \pm 0.91 \mathrm{~mm},-0.05 \pm 0.02 \mathrm{~mm}$ and $-1.69 \pm 0.9 \mathrm{~mm}$ respectively for distal measurements. Kolerman et al ${ }^{20}$ reported the follow-up time which varied between 6 and 14 months the mean vertical mesial bone loss was $1.81 \mathrm{~mm} \pm 1.07$, and the mean vertical distal bone loss was $1.74 \mathrm{~mm} \pm 1.12$. In eight patients, at least one implant presented bone loss of $\geq 3 \mathrm{~mm}$. Tang et al ${ }^{1}$ reported that in the group where patients received ridge splitting and expansion in conjunction with guided bone regeneration the bone loss (vertically) after expansion was $1.60 \pm 0.81 \mathrm{~mm}$ after 7 months of unloaded healing, and the marginal bone loss after loading was $0.43 \pm 0.51 \mathrm{~mm}$ during the first year, followed by $0.06,0.08,0.06,0.08$, and $0.09 \mathrm{~mm}$ annually. Garcez-Filho et $\mathrm{al}^{26}$ documented that the marginal bone loss around implants was $0.47 \pm$ $0.91 \mathrm{~mm}$ at 6 months after loading and $1.93 \pm 0.93 \mathrm{~mm}$ at 10 years follow up after loading. Mounir et al ${ }^{17}$ reported that the mean marginal bone loss (in a follow up of 6 months postoperatively) of the labial plate in the control group (ridge-splitting technique using a full thickness mucoperiosteal flap) was found to be $2.29 \mathrm{~mm}(15.36 \%$ ) (labially), $2.48 \mathrm{~mm}(16.84 \%)$ (palatally) and $1.83 \mathrm{~mm}(12.21 \%)$ (mesio-distally). While in the study group (ridge splitting technique using a partial thickness mucosal flap) it was $0.71 \mathrm{~mm}(5.89 \%)$ (labially), $1.14 \mathrm{~mm}(8.99 \%)$ (palatally) and $1.15 \mathrm{~mm}(8.77 \%)$ (mesio-distally).

Flap design is an important factor that should be put into consideration in reviewing the results of the present contemplate. Some studies applied the partial thickness flap instead of the full thickness flap ${ }^{1,17,18,19,23}$. In their randomized controlled clinical trial, Mounir et al ${ }^{17}$ reported decrease in the amount of crestal bone loss (labial, palatal and mesio-distal) in the patients where partial thickness flap were used in conjunction with split-crest procedure in comparison with full thickness flap. Tang et al ${ }^{1}$ correlated the type of flap to be used with the severity of width insufficiency. They assumed that partial thickness flap could be used when the alveolar width is $4 \mathrm{~mm}$ or more while full thickness flap could be used when the width is less than $4 \mathrm{~mm}$ which needs guided bone regeneration in conjunction with split-crest procedure. Bassetti et $\mathrm{al}^{18}$ stated the necessity for full thickness flap in where releasing (vertical) bone cuts are needed, as proper visualization has to be achieved. The results of the present study should be considered with caution regarding the presence of the flap design as a factor that could affect the amount of crestal bone loss postoperatively in both groups.

During reviewing complications related to the techniques used, we did not investigate fractures or cracks happened to the buccal bone plates in some cases. We think that this is an operator related not a technique related complication. Other complications happened postoperatively which was mentioned in both groups. In group (1), one case was reported with prolonged pain in the expanded area with complete resolution after 1 month postoperatively. In group (2), 2 cases were reported with sudden increase in the incidence of infection. Membrane exposure and dehiscence occurred in 6 sites in two studies ${ }^{8,20}$. Spontaneous exposure in 8 implants was reported in one study ${ }^{20}$.

\section{Conclusion:-}

In conclusion, the studies included in this review showed high success and survival rates of implants placed in narrow ridges where ridge splitting and/or expansion technique were used with/without the application of guided bone regeneration. While the conjunction of guided bone regeneration with the ridge splitting and/or expansion technique showed more complications as membranes exposure and infection. Flap design could be an important factor that could affect the alveolar bone dimensional changes postoperatively. Studies included in the present review were of high or moderate risk of bias with only one randomized controlled clinical trial. So, the results of the 
present study should be reviewed cautiously. Properly designed randomized controlled clinical trials are strongly recommended aiming for further analysis of the effect of guided bone regeneration on ridge splitting with/without expansion technique.

\section{References:-}

1. Tang YL, Yuan J, Song YL, Ma W, Chao X, Li DH. Ridge expansion alone or in combination with guided bone regeneration to facilitate implant placement in narrow alveolar ridges: A retrospective study. Clin Oral Implants Res. 2015;26:204-211.

2. Aghaloo TL, Moy PK. Which Hard Tissue Augmentation Techniques Are the Most Successful in Furnishing Bony Support for Implant Placement? Int J Oral Maxillofac Implants. 2007;49:222-232.

3. Van den Bergh JP, ten Bruggenkate CM, Tuinzing DB, et al. Preimplant surgery of the bony tissues. J Prosthet Dent. 1998;80:175-183.

4. Chiapasco M, Zaniboni M, Boisco M. Augmentation procedures for the rehabilitation of deficient edentulous ridges with oral implants. Clin Oral Implants Res. 2006;17:136-159.

5. McAllister BS, Haghighat K. Bone augmentation techniques. J Periodontol. 2007;78:377-396.

6. Scipioni A, Bruschi GB, Calesini G, Bruschi E, De Martino C. Bone regeneration in the edentulous ridge expansion technique: histologic and ultrastructural study of 20 clinical cases. Int J Periodontics Restorative Dent. 1999;19:269-277.

7. Elian N, Jalbout Z, Ehrlich B, et al. A two-stage full-arch ridge expansion technique: review of the literature and clinical guidelines. Implant Dent. 2008;17:16-23.

8. Simion M, Baldoni M, Zaffe D. Jawbone enlargement using immediate implant placement associated with a split-crest technique and guided tissue regeneration. Int J Periodontics Restorative Dent. 1992;12:462-473.

9. Han J-Y, Shin S-I, Herr Y, Kwon Y-H, Chung J-H. The effects of bone grafting material and a collagen membrane in the ridge splitting technique: an experimental study in dogs. Clin Oral Implants Res. 2011;22:1391-1398.

10. Blus C, Szmukler-moncler S. Split-crest and immediate implant placement with ultra-sonic bone surgery: A 3year life-table analysis with 230 treated sites. Clin Oral Implants Res. 2006;17:700-707.

11. Cordaro L, Amadé DS, Cordaro M. Clinical results of alveolar ridge augmentation with mandibular block bone grafts in partially edentulous patients prior to implant placement. Clin Oral Implants Res. 2002;13:103-111.

12. Chiapasco M, Romeo E, Vogel G. Tridimensional reconstruction of knife-edge edentulous maxillae by sinus elevation, onlay grafts, and sagittal osteotomy of the anterior maxilla: preliminary surgical and prosthetic results. Int J Oral Maxillofac Implants. 1998;13:394-399.

13. Malchiodi L, Scarano A, Quaranta M, Piattelli A. Rigid fixation by means of titanium mesh in edentulous ridge expansion for horizontal ridge augmentation in the maxilla. Int J Oral Maxillofac Implants. 1998; 13:701-705.

14. Enislidis G, Wittwer G, Ewers R. Preliminary report on a staged ridge splitting technique for implant placement in the mandible: a technical note. Int J Oral Maxillofac Implants. 2006; 21:445-449.

15. Danza M, Guidi R, Carinci F. Comparison Between Implants Inserted Into Piezo Split and Unsplit Alveolar Crests. J Oral Maxillofac Surg. 2009;67:2460-2465.

16. Chiapasco M, Ferrini F, Casentini P, et al. Dental implants placed in expanded narrow edentulous ridges with the Extension Crest device. A 1-3-year multicenter follow-up study. Clin Oral Implants Res. 2006;17:265-272.

17. Mounir M, Beheiri G, El-Beialy W. Assessment of marginal bone loss using full thickness versus partial thickness flaps for alveolar ridge splitting and immediate implant placement in the anterior maxilla. Int J Oral Maxillofac Surg. 2014;43:1373-1380.

18. Bassetti R, Bassetti M, Mericske-Stern R, Enkling N. Piezoelectric Alveolar Ridge-Splitting Technique with Simultaneous Implant Placement: A Cohort Study with 2-Year Radiographic Results. Int J Oral Maxillofac Implants. 2013;28:1570-1580.

19. Crespi R, Capparè P, Gherlone EF. Electrical mallet provides essential advantages in split-crest and immediate implant placement. Oral Maxillofac Surg. 2014;18:59-64.

20. Kolerman R, Nissan J, Tal H. Combined Osteotome-Induced Ridge Expansion and Guided Bone Regeneration Simultaneous with Implant Placement: A Biometric Study. Clin Implant Dent Relat Res. 2013; 33:691-704.

21. Sohn DS, Lee HJ, Heo JU, Moon JW, Park IS, Romanos GE. Immediate and delayed lateral ridge expansion technique in the atrophic posterior mandibular ridge. J Oral Maxillofac Surg. 2010;68:2283-2290.

22. Engelke WG, Diederichs CG, Jacobs HG, Deckwer I. Alveolar reconstruction with splitting osteotomy and microfixation of implants. Int J Oral Maxillofac Implants. 1997;12:310-318.

23. Sethi A, Kaus T. Maxillary ridge expansion with simultaneous implant placement: 5-year results of an ongoing clinical study. Int J Oral Maxillofac Implants. 2000;15:491-499. 
24. Langer B, Langer L, Sullivan RM. Planned labial plate advancement with simultaneous single implant placement for narrow anterior ridges followed by reentry confirmation. Int J Periodontics Restorative Dent. 2012;32:509-519.

25. Rahpeyma A, Khajehahmadi S, Hosseini VR. Lateral ridge split and immediate implant placement in moderately resorbed alveolar ridges: How much is the added width? Dent Res J (Isfahan). 2013;10:602-608.

26. Garcez-Filho J, Tolentino L, Sukekava F, Seabra M, Cesar-Neto JB, Araújo MG. Long-term outcomes from implants installed by using split-crest technique in posterior maxillae: 10 years of follow-up. Clin Oral Implants Res. 2014;26:326-331.

27. Scarano A, Murmura G, Sinjiari B, et al. Expansion of the alveolar bone crest with ultrasonic surgery device: Clinical study in mandible. Int J Immunopathol Pharmacol. 2011;24:71-75.

28. Scipioni A, Bruschi GB, Calesini G. The edentulous ridge expansion technique: a five-year study. Int $\mathrm{J}$ Periodontics Restorative Dent. 1994;14:451-459.

29. Schwartz-Arad D, Chaushu G. The Ways and Wherefores of Immediate Placement of Implants Into Fresh Extraction Sites: A Literature Review. J Periodontol. 1997;68:915-923.

30. Bassetti MA, Bassetti RG, Bosshardt DD. The alveolar ridge splitting/expansion technique: a systematic review. Clin Oral Implants Res. 2016;27:310-324.

31. Elnayef B, Monje A, Lin G-H, et al. Alveolar Ridge Split on Horizontal Bone Augmentation: A Systematic Review. Int J Oral Maxillofac Implants. 2015;30:596-606.

32. Jensen OT, Cullum DR, Baer D. Marginal Bone Stability Using 3 Different Flap Approaches for Alveolar Split Expansion for Dental Implants-A 1-Year Clinical Study. J Oral Maxillofac Surg. 2009;67:1921-1930.

33. Demetriades N, Park J Il, Laskarides C. Alternative bone expansion technique for implant placement in atrophic edentulous maxilla and mandible. J Oral Implantol. 2011;37:463-471.

34. Montero J, López-Valverde A, de Diego RG. A retrospective study of the risk factors for ridge expansion with self-tapping osteotomes in dental implant surgery. Int J Oral Maxillofac Implants. 2016; 27:203-210.

35. Anitua E, Begoña L, Orive G. Clinical evaluation of split-crest technique with ultrasonic bone surgery for narrow ridge expansion: status of soft and hard tissues and implant success. Clin Implant Dent Relat Res. 2013;15:176-187.

36. Shibuya Y, Yabase A, Ishida S, Kobayashi M, Komori T. Outcomes and treatments of mal fractures caused by the split-crest technique in the mandible. Kobe J Med Sci. 2014; 60:E37-E42. 